\title{
Incidence of Klumpke's birth palsy: Comparison between two decades
}

\author{
AAF El-Sayed FRCSC, Mohammed Al-Qattan MB BS FRCSC, Howard M Clarke MD \\ PhD FRCSC, CG Curtis BSc PT \\ Department of Plastic Surgery and Obstetrics, King Saud University, Riyadh, Saudi \\ Arabia; Departments of Plastic Surgery and Rehabilitation Services, The Hospital for \\ Sick Children, Toronto, Ontario
}

\begin{abstract}
AAF El-Sayed, MM Al-Qattan, HM Clarke, CG Curtis. Incidence of Klumpke's birth palsy: Comparison between two decades. Can J Plast Surg 1996;4(2):111-113. In a previous paper, the incidence of Klumpke's palsy as cited in the English literature over the last decade (1984 to 1994) was found to be $0.6 \%$. However, during the last decade, there have been consistent increases of cesarean section rates. Therefore, it was unknown if this modern obstetric practice affected the incidence of Klumpke's palsy. This review demonstrates that Klumpke's palsy was equally rare $(0.7 \%$ of birth palsies $)$ in the previous decade (1973 to 1983). It is also shown that 16 out of the 26 cases of Kumpke's palsy reported in the literature over the last two decades were reported from one centre. It is concluded that the incidence of this rare type of birth palsy has not changed with modern obstetric practice and that this palsy is related to vaginal breech deliveries with hyperabduction of the arms.
\end{abstract}

Key Words: Birth injury, Klumpke’s palsy, Obstetric brachial plexus palsy

\section{Incidence du syndrome de Déjérine-Klumpke : comparaison entre deux décennies}

RÉSUMÉ : Dans un article précédent, l'incidence du syndrome de Déjérine-Klumpke citée dans la littérature de langue anglaise lors de la dernière décennie (1984-1994) était évaluée à $0,6 \%$. Or, au cours de la derniére décennie, le taux de césarienne a constamment augmenté et on ignore si cette pratique obstétricale moderne a affecté l'incidence du syndrome de Déjérine-Klumpke. Cette synthèse démontre que le syndrome de Déjérine-Klumpke était tout aussi rare $(0,7 \%$ des paralysies congénitales) au cours de la décennie précédente (1973-1983). On démontre également que 16 cas de syndrome de Déjérine-Klumpke sur 26 signalés dans la littérature au cours des deux dernières décennies provenaient d'un seul centre. Il en a été conclu que les pratiques obstétricales modernes n'ont pas modifié l'incidence de ce rare type de paralysie congénitale et que cette dernière est liée aux présentations de siège avec hyperabduction des bras.

Obstetric brachial plexus palsy is classified into upper, lower, total and intermediate palsies (1) according to the injured roots of the brachial plexus (Table 1).

In a previous paper (2), we reviewed the English literature over the last 11 years (1984 to 1994) and determined the incidence of Klumpke's birth palsy to be $0.6 \%$. 
In this paper, we determine the incidence of Klumpke's birth palsy as cited in the English literature between 1973 and 1983 and compare the results with our previous review (2).

TABLE 1: Classification of brachial plexus birth palsy

$\begin{array}{lll}\text { Type of palsy } & \text { Given names } & \begin{array}{l}\text { Injured roots of the brachial } \\ \text { plexus }\end{array} \\ \text { Upper } & \text { Erb-Duchenne } & \mathrm{C} 5, \mathrm{C} 6 \pm \mathrm{C} 7 \\ \text { Lower } & \text { Klumpke } & \mathrm{C} 8, \mathrm{TI} \\ \text { Total } & \text { Combined } & \mathrm{C} 5, \mathrm{C} 6, \mathrm{C} 7, \mathrm{C} 8 \pm \mathrm{TI} \\ \text { Intermediate } & \text { Jolly-Thomas } & \text { Predominant lesion in } \mathrm{C} 7\end{array}$

\section{MATERIALS AND METHODS}

A MEDLINE search between 1973 and 1983 was performed and the articles were reviewed to determine the incidence of Klumpke's birth palsy among reported cases of obstetric paralysis. The percentage of vaginal breech deliveries in the reports with Klumpke's palsy was also determined. These results were then compared with our previous review (2) of Klumpke's palsy in the English literature between 1984 and 1994.

\section{RESULTS}

The MEDLINE search revealed that none of the review articles on birth palsy (38 ) investigated the actual incidence of Klumpke's palsy in the literature. We classified the papers reporting on brachial plexus birth palsy into two groups. In the first group, the authors (9-17) did not specify the type of palsy in their cases (Table 2). In the second group, the type of palsy was documented and these series (18-48) are shown in Table 3. Klumpke's palsy was seen in $0.7 \%$ of 912 cases of brachial plexus injury published between 1973 and 1983. This percentage is almost the same during the last decade $(0.6 \%)$ as determined from our previous review (2).

TABLE 2: Clinical cases of obstetric brachial plexus palsy published between 1973 and 1983 where authors did not specify the type of palsy in their cases

Reference
9
10
11
12
13
14
15
16
17

Authors

Boyd et al

Green et al

Hoffer et al

Manske et al

Neuenschwander et al

Ohlsen

Parks and Ziel

Stefanova-Uzaunova et al

Svigos

Total
Number of obstetric plexus palsy

cases

15

25

45

11

20

11

3

17

6

153 
TABLE 3: Series of obstetric brachial plexus palsy published between 1973 and 1983 in which the type of paralysis has been documented

$\begin{array}{cl}\text { Reference } & \text { Authors } \\ 18 & \text { Aston } \\ 19 & \text { Bennet and Harrold } \\ 20 & \text { Eng et al } \\ 21 & \text { Gordon et al } \\ 22 & \text { Hoffer et al } \\ 23 & \text { Johnson et al } \\ 24 & \text { Perry et al } \\ 25 & \text { Rossi et al } \\ 26 & \text { Specht } \\ 27 & \text { Tan } \\ 28 & \text { Zancolli } \\ 29-48^{*} & \text { Others } \\ & \text { Total }\end{array}$

\begin{tabular}{cc} 
Total number of birth palsy & \multicolumn{2}{l}{ Number of Klumpke's palsy } \\
cases & 3 \\
80 & 0 \\
24 & 0 \\
135 & 0 \\
58 & 0 \\
39 & 0 \\
32 & 0 \\
10 & 3 \\
34 & 0 \\
11 & 0 \\
57 & 0 \\
368 & 0 \\
64 & $6(0.7 \%)$ \\
912 &
\end{tabular}

*References 29-48 are other articles that included less than 10 cases. Hardy (38) reported on 36 cases but he only documented the type of paralysis in the seven patients who did not recover spontaneously

The method of delivery in the reported cases of Klumpke's palsy was not specifically mentioned but the total percentage of vaginal breech deliveries in these series was higher than the Toronto series (2). Similar findings were observed in our previous review (Table 4) $(2,18,25,49-51)$.

TABLE 4: Percentage of vaginal breech deliveries in the Toronto series compared with other reports with Klumpke's palsy published over the last two decades

\begin{tabular}{|c|c|c|c|c|}
\hline & Authors & $\begin{array}{c}\text { Total number of } \\
\text { birth palsy cases }\end{array}$ & $\begin{array}{l}\text { Percentage of vaginal breach } \\
\text { deliveries in the series }\end{array}$ & $\begin{array}{c}\text { Number of Klumpke's } \\
\text { palsy cases }\end{array}$ \\
\hline Toronto series & Clarke (2) & 235 & $2.6 \%$ & 0 \\
\hline \multirow[t]{3}{*}{$\begin{array}{l}\text { Reports published } \\
\text { between } 1984 \text { and } 1994\end{array}$} & $\begin{array}{l}\text { Stojcevic } \\
\text { Polovina (49) }\end{array}$ & 265 & $20.1 \%$ & 16 \\
\hline & $\begin{array}{l}\text { Al Rajeh et al } \\
(50)\end{array}$ & 57 & $8.8 \%$ & 1 \\
\hline & $\begin{array}{l}\text { Jahnke et al } \\
\text { (51) }\end{array}$ & 64 & $6.3 \%$ & 3 \\
\hline \multirow[t]{2}{*}{$\begin{array}{l}\text { Reports published } \\
\text { between } 1973 \text { and } 1983\end{array}$} & Aston (18) & 80 & $13.8 \%$ & 3 \\
\hline & Rossi et al (25) & 34 & $17.6 \%$ & 3 \\
\hline
\end{tabular}

\section{DISCUSSION}

Isolated C8/TI lesions in birth injuries are related to vaginal breech deliveries with hyperabduction of the arms. Before our reviews, the incidence of Klumpke's birth palsy was unknown. Our first paper (2) determined the incidence of this type of palsy to be 0.6\%, as cited in the English literature between 1984 and 1994. During the same decade, there had been an increase in cesarian section rates (52). Therefore, it was questioned 
whether this obstetric practice affected the incidence of Klumpke's palsy. In the current study, we demonstrated that this palsy was equally rare $(0.7 \%)$ in the previous decade. Prevention of Klumpke's palsy in vaginal breech delivery is best done by not allowing the arms to hyperabduct which puts the eighth cervical and first thoracic roots on a stretch (53). This fact has been known by obstetricians for several decades and since the cadaveric studies done by Sever in 1916 (53). An important finding of the current review was the high percentage of vaginal breech deliveries in the reports with Klumpke's palsy and this was true for the last two decades (Table 4). It was also interesting to note that 16 out of the 26 cases of Klumpke's palsy reported in the English literature over the last two decades were reported from one centre (Table 4).

In conclusion, Klumpke's palsy is extremely rare and its incidence has not changed with modern obstetric practice. This palsy appears to be related to vaginal breech deliveries with hyperabduction of the arms.

\section{REFERENCES}

1. Al-Qattan MM, Clarke HM. A fourth type of brachial plexus lesion: The intermediate (C7) palsy. J Hand Surg 1994;19B:673.

2. Al-Qattan MM, Clarke HM, Curtis CG. Klumpke's birth palsy. Does it really exist? J Hand Surg 1995;20B:19-23.

3. Chung SMK, Nissenbaum MM. Obstetrical paralysis. Orthop Clin North Am 1975;6:393-400.

4. Curran JS. Birth associated injury. Clin Perinatol 1981;8:111-29.

5. Hensinger RN, Jones ET. Developmental orthopaedics. 2: The spine, trauma, and infection. Develop Med Child Neurol 1982;24:202-18.

6. Painter MJ, Bergman I. Obstetrical trauma to the neonatal central and peripheral nervous system. Seminars Perinatol 1982;6:89-104.

7. Donn SM, Faix RG. Long term prognosis for the infant with severe birth trauma. Clin Perinatol 1983;10:507-20.

8. Faix RG, Donn SM. Immediate management of the traumatized infant. Clin Perinatol 1983;10:487-505.

9. Boyd ME, Usher RH, McLean FH. Fetal macrosomia: Prediction, risks, proposed management. Obstet Gynecol 1983;61:715-22.

10. Green JE, McLean F, Smith LP, Usher P. Has an increased cesarean section rate for term breech delivery reduced the incidence of birth asphyxia, trauma and death? Am J Obstet Gynecol 1982;142:643-8.

11. Hoffer MM, Braun R, Hsu J, Mitani M, Temes K. Functional recovery and orthopedic management of brachial plexus palsies. JAMA 1981;246:2467-70.

12. Manske PR, McCarrol HR Jr, Hale R. Biceps tendon rerouting and percutaneous osteoclasis in the treatment of supination deformity in obstetrical palsy. J Hand Surg 1980;5:153-9.

13. Neuenschwander S, Brauner M, Gilbert A, Faure C. Cervical myelography with metrizamide in brachial birth palsies. Ann Radiol (Paris) 1980;23:93-8.

14. Ohlsen H. Outcome of term breech delivery in primigravida. A feto pelvic breech index. Acta Obstet Gynecol Scand 1975;54:141-51. 
15. Parks DG, Ziel HK. Macrosomia. A proposed indication for primary cesarean section. Obstet Gynecol 1978;52:407-9.

16. Stefanova-Uzunova M, Stamatova L, Gatev V. Dynamic properties of partially denervated muscle in children with brachial plexus birth palsy. J Neurol Neurosurg Psych 1981;44:497-502.

17. Svigos JM. The macrosomic infant. A high risk complication. Med J Aust 1981;1:245-6.

18. Aston JW Jr. Brachial plexus birth palsy. Orthopedics 1979;2:594-601.

19. Bennet GC, Harrold AJ. Prognosis and early management of birth injuries to the brachial plexus. BMJ 1976;i:1520-1.

20. Eng GD, Koch B, Smokvina MD. Brachial plexus palsy in neonates and children. Arch Phys Med Rehab 1978;59:458-64.

21. Gordon M, Rich H, Deutschberger J, Green M. The immediate and long term outcome of obstetric birth trauma. 1: Brachial plexus paralysis. Am J Obstet Gynecol 1973;117:51-6.

22. Hoffer MM, Wickenden R, Roper B. Brachial plexus birth palsies. Results of tendon transfers to the rotator cuff. J Bone Joint Surg 1978;60A:691-5.

23. Johnson EW, Alexander MA, Koenig WC. Infantile Erb's palsy (Smellie's palsy). Arch Phys Med Rehab 1977;58:175-8.

24. Perry J, Hsu J, Barber L, Hoffer MM. Orthoses in patients with brachial plexus injuries. Arch Phys Med Rehab 1974;55:134-7.

25. Rossi LN, Vassella F, Mumenthaler M. Obstetrical lesions of the brachial plexus. Natural history in 34 personal cases. European Neurol 1982;21:1-7.

26. Specht EE. Brachial plexus palsy in the newborn. Incidence and prognosis. Clin Orthop 1975;110:32-4.

27. Tan KL. Brachial palsy. J Obstet Gynecol BR Comm 1973;80:60-2.

28. Zancolli EA. Classification and management of the shoulder in birth palsy. Orthop Clin North Am 1981;12:433-57.

29. Anagnostakis D, Economou-Mavrou C, Moschos A, Vlachos P, Liakakos D.

Diaphragmatic paralysis in the newborn. Arch Disease Childhood 1973;48:977-9.

30. Benedetti TJ, Gabbe SG. Shoulder dystocia. A complication of fetal macrosomia and prolonged second stage of labor with midpelvic delivery. Obstet Gynecol 1978;52:526-9. 31. Bowen TE, Zajtchuk R, Albus RA. Diaphragmatic paralysis managed by diaphragmatic replacement. Ann Thoracic Surg 1982;33:184-8.

32. Cohen AW, Otto SR. Obstetric claricular fractures. A three-year analysis. J Reproduc Med 1980;25:119-22.

33. Collea JV, Rabin SC, Weghorst GR, Qulligan EJ. The randomized management of term frank breech presentation: Vaginal delivery vs cesarean section. Am J Obstet Gynecol 1978; 131:186-93.

34. Cuesta FJG, Parts FL, Lopez FJG, Sitja JB. The role of bone operations as palliative surgical treatment for the sequelae of obstetrical brachial paralysis in the shoulder. Acta Orthop Belgica 1982;48:757-61.

35. De Grandis D, Fiaschi A, Michieli G, Mezzina C. Anomalous reinnervation as a sequel to obstetric brachial plexus palsy. J Neurol Sci 1979;43:127-32.

36. Greene W, L'Heureux P, Hunt CE. Paralysis of the diaphragm.

Am J Diseases Children 1975;129:1402-5. 
37. Haller JA Jr, Pickard LR, Tepas JJ, et al. Management of diaphragmatic paralysis in infants with special emphasis on selection of patients for operative plication. J Pediatr Surg 1979;14:779-84.

38. Hardy AE. Birth injuries of the brachial plexus. Incidence and prognosis. J Bone Joint Surg 1981;63B:98-101.

39. Khatree MHD, Gamsu HR, Rudd P, Studd JWW. Features predictive of brachial plexus injury during labour. South African Med J 1982;61:232-3.

40. Koenigsberger R. Brachial plexus palsy at birth: Intrauterine or due to delivery trauma. Ann Neurol 1980;8:228. (Abstr)

41. Manske PR. Deltoid muscle abduction contracture. Clin Orthop 1977;128:165-6. 42. Modanlou HD, Dorchester, WL, Thorosian A, Freeman RK. Macrosomia. Maternal, fetal and neonatal implications. Obstet Gynecol 1980;55:420-4.

43. Schwartz MZ, Filler RM. Plication of the diaphragm for symptomatic phrenic nerve paralysis. J Pediat Surg 1978;13:259-63.

44. Solonen KA, Telaranta T, Ryoppy S. Early reconstruction of birth injuries of the brachial plexus. J Pediat Orthop 1981;1:367-70.

45. Symbas PN, Hatcher CR Jr, Waldo W. Diaphragmatic eventration in infancy and childhood. Ann Thoracic Surg 1977;24:113-9.

46. Wayne ER, Campbell JB, Burrington JD, Davis WS. Eventration of the diaphragm. J Pediatr Surg 1974;9:643-50.

47. Weisman L, Woodall J, Merenstein G. Constant negative pressure in the treatment of diaphragmatic paralysis secondary to birth injury.

Birth Defects 1976;12:297-302.

48. Zajkowski EJ, Kravath RE. Bilateral diaphragmatic paralysis in the newborn infant. Chest 1979;75:392-4.

49. Stojcevic-Polovina M. Risk factors in infants with paresis of the brachial plexus. Acta Medica Iugoslavica 1986;40:3-14.

50. Al-Rajeh S, Corea JR, Al-Sibai MH, Al-Umaran K, Sankarankutty M. Congenital brachial palsy in the Eastern Province of Saudi Arabia.

J Child Neurol 1990;5:35-8.

51. Jahnke AH, Bovill DF, Mccarroll HR, James P, Ashley RK. Persistent brachial plexus birth palsies. J Pediatr Orthop 1991;11:533-7.

52. Notzon FC, Placek PJ, Taffel SM. Comparisons of national cesarean section rates. N Engl J Med 1987;316:386-9.

53. Sever JW. Obstetric paralysis: Its etiology, pathology, clinical aspects and treatment, with a report of 470 cases. Am J Diseases Children 1916;12:541-78. 